\title{
Designing Granoolars Brand Promotion with Social Media Mix Approach as A Brand Awareness Strategy
}

\section{Perancangan Promosi Brand Granoolars dengan Pendekatan Bauran Media Sosial sebagai Strategi Brand Awareness}

\author{
Aura Nebula Safinatunnajah, Pujiyanto*, Joni Agung Sudarmanto \\ Universitas Negeri Malang, Jl. Semarang No. 5 Malang, Jawa Timur, Indonesia \\ *Penulis korespondensi, Surel: pujiyanto.fs@um.ac.id
}

Paper received: 05-07-2021; revised: 19-07-2021; accepted: 31-07-2021

\begin{abstract}
Granoolars is a newly established business in the food industry that needs more brand awareness from the target consumers. Promotional content is one of the approaches to reach the audience for recognition. Since the consumer is the value co-creator, a thorough investigation was highlighted on the characteristics that the targeted consumer seeks in an ad, both the verbal and visual aspects. Moreover, the distribution channel of social media that the respondents mostly use was also discussed. The purpose of this study was to comprehend and design the promotional content which the audience approves. The design process uses Matt Cooke methodology which consists of definition, divergence, and transformation stage. The study is a quantitative method using an online survey on 300 respondents. The SPSS data analysis was used for the descriptive statistics analysis. The findings proposed that the respondents prefer marketing content that has the ad value of credibility and informativeness. Moreover, visual of the content that implemented a strong design principle is favorable for the audience of this study. The distribution funnel being adopted are Instagram and Twitter as the most used social media platforms by the respondents.
\end{abstract}

Keywords: brand promotion, social media content, brand awareness

\begin{abstract}
Abstrak
Granoolars adalah bisnis yang baru didirikan di industri makanan yang membutuhkan lebih banyak kesadaran merek dari target konsumennya. Konten promosi adalah salah satu pendekatan untuk menjangkau audiens untuk mendapatkan pengakuan merk. Sebab konsumen adalah value cocreator, penyelidikan menyeluruh difokuskan pada karakteristik yang dicari target konsumen dalam sebuah iklan, baik aspek verbal maupun visual. Selain itu, saluran distribusi media sosial yang paling banyak digunakan responden juga dibahas. Tujuan dari penelitian ini adalah untuk memahami dan merancang konten promosi yang disukai audiens. Proses perancangan menggunakan metodologi Matt Cooke yang terdiri dari tahap definisi, divergensi, dan transformasi. Penelitian ini menggunakan metode kuantitatif dengan menggunakan survei online terhadap 300 responden. Analisis data SPSS digunakan untuk analisis statistic deskriptif. Hasil penelitian menunjukkan bahwa responden lebih menyukai konten pemasaran yang memiliki nilai iklan kredibilitas dan keinformatifan. Selain itu, visual konten yang menerapkan prinsip desain yang kuat sangat disukai oleh audiens penelitian ini. Corong distribusi yang diadopsi adalah Instagram dan Twitter sebagai platform media sosial yang paling banyak digunakan oleh responden.
\end{abstract}

Kata kunci: promosi brand, konten media social, kesadaran merek

\section{Introduction}

The growth of the creative economy sector has been so promising year upon year. Bekraf defines creative economy as the expression of the unique value of human creativity and the creation of intellectual property rights associated on cultural content, science, and technology (Agustina, Winarno, Pratikto, Narmaditya, \& Filianti,, 2020; BEKRAF, 2019). Among the sixteen 
subsectors of the creative economy, the culinary industry is the lead contributor in terms of GDP. BEKRAF or Badan Ekonomi Kreatif (2019) stated that nowadays, the status of culinary in Indonesia will continually advance the entire creative economy sector both as a lifestyle and a leisure activity.

Accordingly, the food and beverage sub sector have a strong basis for innovation and enhances its market size and scope in the foreseeable future. The opportunity of these circumstances has led Granoolars to take part in the food creative industry. Granoolars is a newly born healthy snack brand with a grab-to-go concept and rich in nutrition. The core ingredient of this brand is granola which is a mixture of toasted oatmeal, nuts, dried fruits, and honey. Several products that this business offers are a selection of Granoolars Energy Bar with various toppings, Granoolars Brownie, and Granoolars Cookie. The positioning that Granoolars wish to be associated as a natural, healthy, low calorie, and delightful snack.

As a freshly emerging business, Granoolars need to be known by the target customer in order to earn brand awareness. Nguyen (2020) acknowledged that consumers' capacity to recognize a brand is determined by the effort put forth in establishing an image of the brand. When a business uses marketing and advertising to help its target, consumers identify and recognize the business' identity is known as brand awareness. It is fundamental for business, especially the newly established one, to build brand recognition during the early stages of launching to attract consumers. The promotional approach initiatives must be focused on the value that people care about and must be related to the business itself. The utilization of social media to produce helpful, entertaining, and relevant content is a fresh and extremely successful approach for new business to build brand awareness. This will foster a bond between targeted audience and the business, converting them into prospective consumers (Nguyen, 2020).

In recent years, the advertising emphasis has shifted from push ads into trust-based advertising. The trend among advertisers shows that the marketing's focus on dominant logic has transformed from physical commodities to service dominant logic. The way advertising gives an interactive experience and value co-creation is the cornerstone of customer engagement. Furthermore, customers frequently act in order to create their own unique experiences (Brodie, Hollebeek, Ilić, \& Jurić, 2011). Additionally, Dehghani and Tumer (2015) argue that in order to enhance customer buy intent, a business should provide advertising message content that is relevant to the target audience. As a result, to increase the awareness of the business, the social media advertising message content should mirror the consumer's fundamental value.

Since consumers are the value co-creator, the advertising messages should be parallel with consumer's demand of the content they desire. Both verbal and visual aspects of the promotional content must tap in with the preference of Granoolars' target audience. For optimum visual communication, design principles must be addressed and utilized while designing the promotional content. Earlier research on visuals in advertising has mostly focused on the visual design used inside an advertisement. Both the verbal and visual aspects of an advertisement have the same role in attaining the consumer's awareness of the brand (Marley, 2018).

In consideration of the context or verbal aspect for the advertising message content, a previous study by Hashim, Normalini, and Sajali (2018) incorporate the original model of 
advertising value regarding the message content from R. H. Ducoffe (1996) and MacKenzie and Lutz (1989) on mobile advertising. This empirical study also develops certain changes to be suitable for social media advertising. Therefore, the idea of advertising message content characteristics such as entertainment, informativeness, and credibility is explored in this study. Meanwhile, for the visual elements of the advertisement, Marley (2018) proposed that the ad creatives use graphic design principles to produce visually appealing designs. The different components that, when integrated, produce visual art are basically the principles that make up a great design. The formal principles and approaches for maximizing the layout and appearance of two-dimensional visual elements are design principles.

To be properly accepted, the message must reach consumers at their touchpoint in addition to providing an ad that is strongly correlated with the target population. Social media appears to be an excellent customer touchpoint as technology advances and the popularity of social media grows. Moreover, the target customer for Granoolars coming from the Gen Z which is recognized as the highest social media usage among other generations. Global Web Index stated that the daily average social media spending time of Indonesian Gen $\mathrm{Z}$ has surpassed Millenials. Gen Z consumes 2 hours 55 minutes daily on social media channels. Therefore, the business should consider the social media platforms that the customer utilizes to get advertisements. As a result, businesses can use the synergetic elements of multiple social media platforms to send the promotional messages directly to the targeted audience.

The objective of this study is to give insights on how the Indonesian Gen $\mathrm{Z}$, as the respondent in this research, prefers social media advertising content. The output is to design the appropriate ads material for Granoolars through the social media mix as a brand awareness strategy. Moreover, the findings are expected to aid researchers, marketers, advertisers, and other creatives to understand the distribution channel of Granoolars respondents.

\section{Method}

In order to achieve the research and design objective, it is essential to understand how design could be more successful if it had a more methodological approach. This could be done by looking at important components of the design thinking and making. A design methodology by Matt Cooke is the most relevant approach by adopting a variety of marketing and advertising-related working approaches with the objective to increase the awareness of a social campaign. Additionally, Cooke designed a comprehensive technique that outlined, documented, and implemented a sequence of stages toward a feasible and practical solution (Noble \& Bestley, 2005). Moreover, this consumer-centered design methodology is appropriate to create a variety of contents designed particularly for the targeted consumer (Lehrer, 2006).

The creation process of a design by Cooke's working methodology is presented in three stages, each of which defines the process. They are definition, divergence, and transformation stages. In the definition section, a variety of actions that might assist the designer defining the problem has to be solved. The establishment of specific objectives by analyzing the problem and identifying the target audience should be done in this early stage. Then, divergence as the second phase encompasses a wide range of primary and secondary research methodologies. The aim is to gather a thorough explanation of the context in which the task will be implemented. This process also involves an examination of relevant visual languages for the 
target audience. By the completion of the divergent research, the transformation phase is ready to be implemented. Considering the raw materials can already be implemented into a set of proposed design solutions.

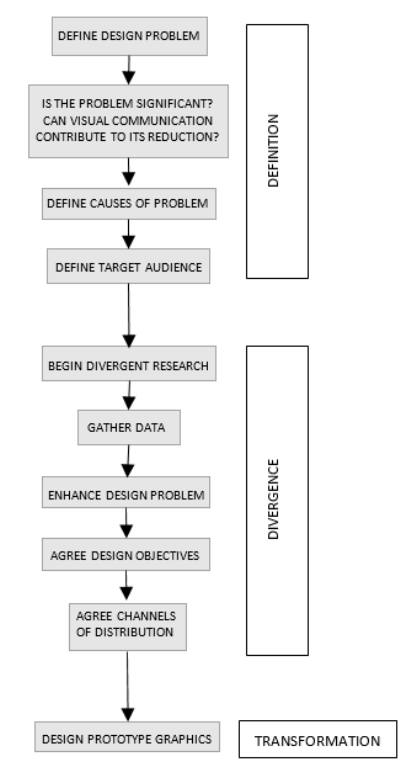

Figure 1. Design Methodology

Source: Adapted Design Methodology by Matt Cooke

This research adopted a quantitative approach, which is a technique that involves measuring data using a numerical system. The objective of collecting quantitative data is to comprehend and characterize the nature of a phenomena. A descriptive method is performed in order to establish and define the features of research variables. The primary goal is to provide a detailed description of the given topic (Sekaran, 2003). In this study, the first phase on verbal content aims to gain the insights from Granoolars target audience on their preference of social media channels and promotional content as the business strategy to increase its brand awareness.

Moreover, for the visual content, the experimental study was used. It aimed at investigating how the design and layout affect the target audience's perceptions of the promoted product or brand. The essential factors were used in the investigation such as unity, emphasis, and perceptual pressures. Six contents characterizing the stimuli were used to modify the predictor variables: strong and weak unity; strong and weak emphasis; strong and weak perceptual forces. Experimental designs provide researchers better support over variables involved, allowing them to find causal correlations (Marley, 2018).

The first item (U1) in the experiment indicated strong unity. It used identical typography, text alignment, and text styles inside paragraphs and lines, as well as repetition of lines, space, fonts, and color schemes. While the second item (U2) showed weak unity by modifying the proximity or arrangement of the text. The text was designed with various type of font, font sizes, text alignment, colors, and the repetition was made inconsistent. 


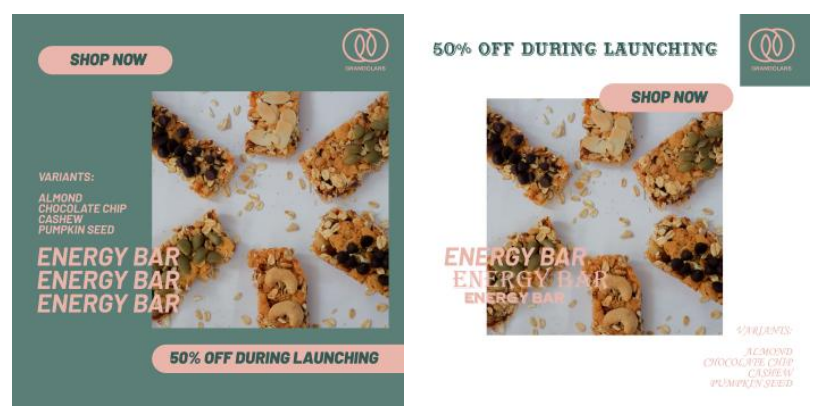

Figure 2. Stimulus for Unity. The left ad demonstrates strong unity (U1) and the right ad demonstrates weak unity (U2)

The next design principle was emphasis. The first item (E1) represents strong emphasis that can be acknowledged from the contrast in the text's color and size of font for the headline. Therefore, the audience can understand the crucial information easily. However, the weak emphasis (E2) was shown through the similar design of the text in the whole ad.
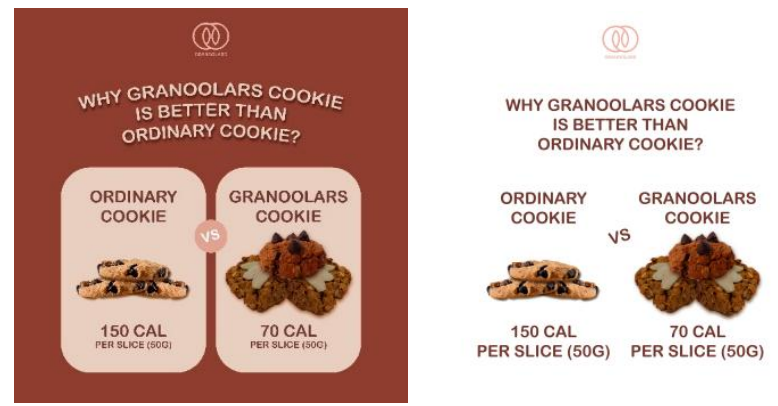

Figure 3. Stimulus for Emphasis. The left ad demonstrates strong emphasis (E1) and the right ad demonstrates weak emphasis (E2)

The last principle was perceptual forces. It is designed for balance, continuity, figureground, and psychological closure (Marley, 2018). The strong perceptual forces (PF1) are designed by the presence of implicit closure at the top text of the content, clear figure-ground from the contrast of the bright background and dark copy, as well as proportional balance. While the weak perceptual forces presented by a strong ground that distract the whole ad. Which made information of the content unclear to be recognized. Moreover, the text was imbalanced due to the left alignment for the whole copy.

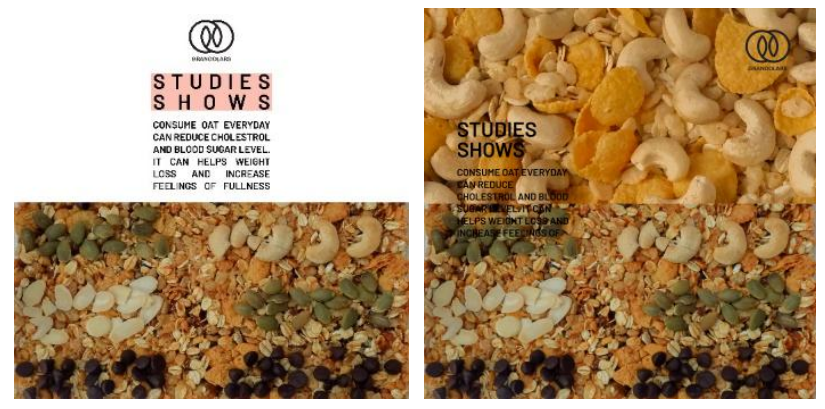

Figure 4 Stimulus for Perceptual Forces. The left ad demonstrates strong perceptual forces (PF1) and the right ad demonstrates weak perceptual forces (PF2) 
Various individuals or things that constitute the core focus of a study which the researcher intends to explore are often used in a research population. It is a group of people or objects that have similar traits (Sekaran, 2003). The population of this research is a target group of Gen Z in Malang that recently used social media as Granoolars segmented market.

While the sampling methodology is a method for calculating sample size. A sample is a part of the population from which various numbers are picked (Sekaran, 2003). Nonprobability sampling approaches were utilized in this study, and the method used was simple purposive sampling, which relies on the subjective evaluation on specific criteria that are thought to be related to population characteristics. Since the demographic was picked from the target audience of Granoolas, the chosen characteristics are Gen Z in Malang. However, not all members of Gen $\mathrm{Z}$ were included in this study because this generation is classified as those born between 1996 and 2012, making their ages vary from 8 to 24. Gen $\mathrm{Z}$ to be included as a population if they are between the ages of 17 and 24 , as this is considered adulthood where their response can be held accountable, and they may freely decide on things. In this study, there are 300 documented respondents.

The primary data is in the form of a survey method with descriptive analysis. While secondary data from open records was used independently. The secondary data for the desk study was gathered via the internet. An extensive literature study was used to start off the study. They vary from publications, e-book, research papers, and reports. Internet sources were being used for more specific data.

Questionnaires were utilized to collect information for this study. The questionnaire is a data collecting tool in which respondents are given a set of written questions or statements to answer. The measuring scale employed in this questionnaire was the 5-Point-Likert Type. The Likert scale has been used to assess a person's or a group's attitudes, views, and perceptions of social phenomenon. The study used online surveys as more convenient and can ensure no data is lost or misplaced (Sekaran, 2003). The survey was created with Google Form and shared over numerous social media channels, including Instagram, WhatsApp, Twitter, and Line.

The kind of query used in this study was a mix of closed and open-ended questions, in which participants were allowed to pick from a list of options given by the researcher. According to Sekaran (2003), closed-ended questions let responders make faster decisions from a list of possibilities. This sort of inquiry made it simple for the researcher to record the information for later evaluation.

\section{Findings and Discussion}

\subsection{Definition}

Definition is the initial step in the design process. This is where the project's initial outline is established. Several questions are asked at this stage to determine the scope of the problem and determine if visual communications can contribute significantly to its resolutions.

\subsubsection{Define Design Problem}

The design methodology's initial task is to determine and characterize the design challenge beforehand. Identifying the design challenge explicitly from the beginning provides the researcher an opportunity to begin when tackling the project. As a new brand in the market 
of the food industry, specifically the healthy product, Granoolars need to be known by the target consumer. For that reason, it is critical for business that just getting started to develop brand awareness early on. The promotional strategy activities must be centered on the value that people care about and connected to the business. This value can be specified into the kind of content that the target audience preferred and the distribution channels of the message that they use, which in this case is social media platform. Therefore, the design problem was to raise awareness of Granoolars by creating the brand promotion with a social media mix approach as the strategy.

Given that gaining brand awareness can help a new business to reach the target market in the early stage of the launching and therefore can possibly bring sales to the business, it became constantly undeniable that the design problem is crucial. Since there is clear evidence on design-added value to business, most organizations agree that design offers a great contribution to the brand. Yu (2006) acknowledged that previous research shows that design contributes a significant growth on business practice.

\subsubsection{Define Causes of Problem}

The problem addressed was to design the Granoolars brand promotions by the approach of social media mix as the promotional strategy. The underlying reason for the design problem was that the Granoolars brand had just started to launch and needed to drive its brand awareness towards the target consumers.

\subsubsection{Define Target Audience}

In delivering the promotional contents, the primary need is to define the intended consumer by the Granoolars brand. As this is critical to meet the objective of the study in designing the advertising content with the social media mix approach as the strategy to increase the brand awareness. Based on the analysis of target audience by Granoolars, the following are the intended consumer:

1) Demographic

a) Gender: Male and Female

b) Age range: 17-24-year-old

c) Economic and Social Status: Middle-High

d) Education: High School up to master's degree

e) Occupation: a wide range from a student up to a busy office worker

2) Geographic

Malang districts and Malang City Area

3) Psychographic

Individuals that have interests and lifestyles to maintain and live a healthy life.

4) Behavioral

a) Benefit Sought: instant grab-to-go and high nutritional snack

b) Social media active user

\subsection{Divergence}

Divergence encompasses a wide range of primary and secondary research methodologies, resulting in a thorough description of the scenario in which the project will 
operate. This also includes an examination of related materials of the visual space such as a relevant visual language for the intended audience.

\subsubsection{Gather Data}

Data collection is an approach to learn more about the target audience, to comprehend their preferences, and to discover what drives and excites them. To put it another way, the goal is to acquire some of their beliefs and to try to understand their communication - both verbal and visual. People favor what they already recognize, and it is consequently difficult to communicate without adopting the audience's language in both style and substance (Noble \& Bestley, 2005). Therefore, data on verbal and visual preference of the Granoolars' target audience is extremely important.

\section{Verbal Content in Advertising}

The concept of advertisements has evolved in the current era of advertising. Consumer engagement is improved by elements such as interaction and personalization, which are based on the marketing concept of service dominating logic. Consumer interest in advertisements is driven by the interactive experience and value co-creation (Brodie et al., 2011).

Therefore, in an advertising environment, the service dominating logic is acknowledged for offering customers unique benefits of value co-creation in order to build an immersive experience. This is also in line with the shift in advertising from a push to a pull technique for determining a consumer's worth. Since social media continues to grow in popularity, marketers and advertisers have a better understanding of the potential richness of advertising message content and their targeting approach.

When it comes to social media marketing, content is everything. Nguyen (2020) mentioned that about $90 \%$ of respondents indicated they only want to view business content if it will empower or entertain them. He also claims that viewers would not go for a brand at whatever point unless it can provide relevant and entertaining content while putting the advertising motive aside. Rodgers and Thorson (2018) mentioned that the most important aspect of advertising media and content is that it may influence a consumer's behavior, such as the increasing of awareness for a brand.

The objective of advertising message content is to alter consumer behavior by attracting and maintaining customers through the creation and distribution of relevant and related content (Pulizzi, 2012). Therefore, referring to the study by Hashim et al. (2018) while using the model from Ducoffe (1996) and MacKenzie and Lutz (1989) on the features of the ads message content are explored as the theoretical framework based on the approach of advertising value. There is entertainment, informativeness, and credibility.

The capacity to evoke aesthetic delight during the engagement with digital media, which adds to cognitive process, is referred to as entertainment. Furthermore, entertainment needs a message that is both clear and humorous. It is feasible to say that getting an entertainment value in an advertising message with aspects of (1) delightful, (2) entertaining, (3) brief, (4) funny, (5) aesthetic satisfaction, and (6) rich in multimedia use such as pictures and movies with music. 
Meanwhile the capacity of advertising to properly enlighten consumers about products or services and offer relevant product information is referred to as informativeness (Siau \& Shen, 2003). It is a situation that allows business to offer vital or interesting facts while also getting a valuable source of product information. The capacity to provide correct product information and information that is up to date. An advertising message's information must include (1) high-quality content, (2) correctness, (3) timely delivery, (4) customer utility, and (5) rapid accessibility.

The extent to which the customer believes the information presented in the advertising about the brand is accurate and credible. Ad credibility is critical for the customer perceived value, which is linked to content predictions and fulfillment (Hashim et al., 2018). Consumers' evaluations of social media advertising as (1) believable, (2) unbiased, and (3) compelling can be used to assess content's credibility.

The respondents in this survey are Gen Zers in Malang that are frequently on social media. The Gen Z participants in the research are between the ages of 17 and 24 and have at least once experienced social media ads. The total number of Gen $\mathrm{Z}$ respondents who responded to the questionnaire as a data collecting technique is 300 . The following is a breakdown of the participant's answers.

Table 1. The Distribution Frequency of Respondent's Answer on Advertising Value

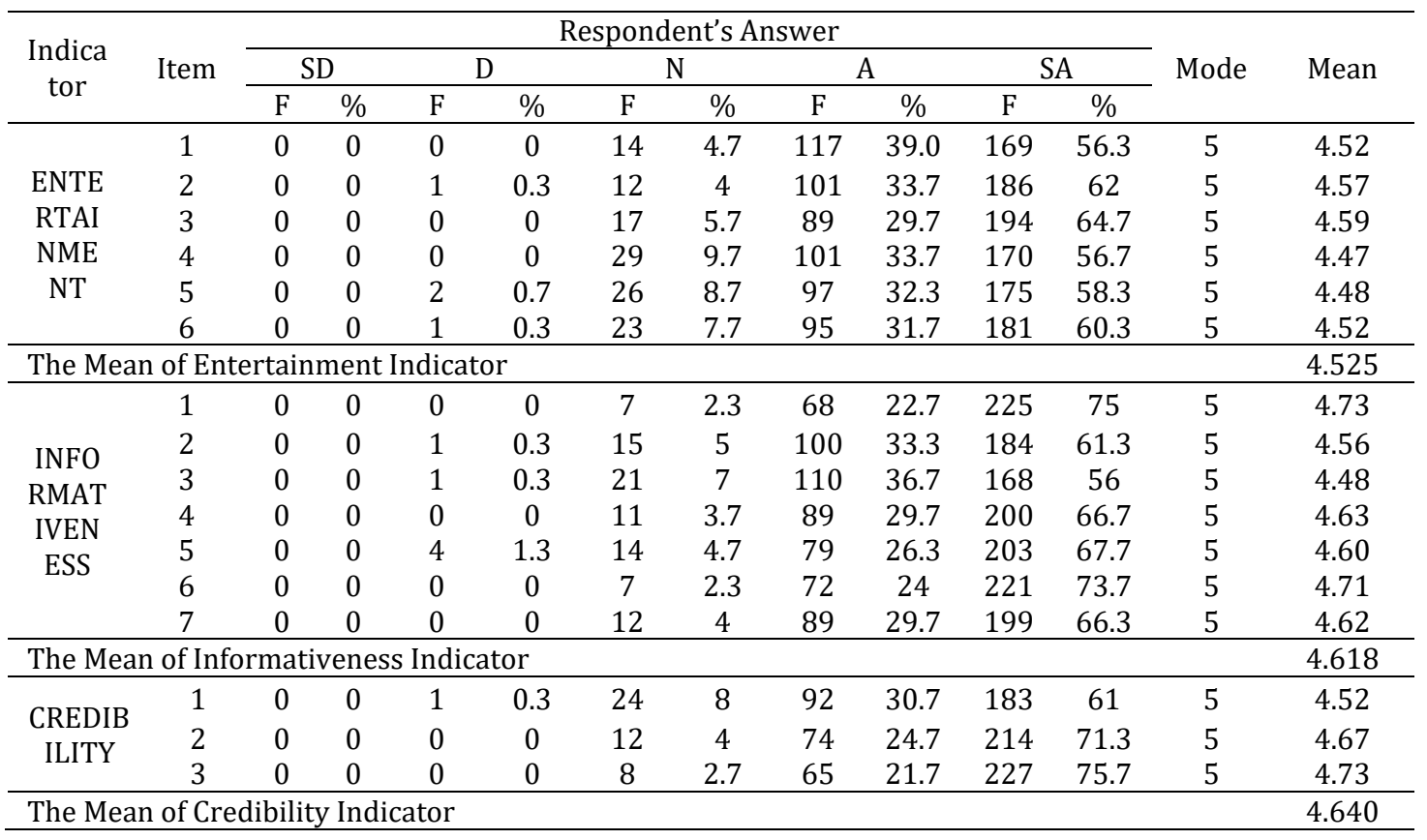

In Table 1 credibility has the greatest average value amongst those three factors of entertainment, informativeness, and credibility. The average score for the credibility is 4.640. This means that respondents expect to see a credible ad during the time they spend in social media. The utmost objective that the Gen $\mathrm{Z}$ in Malang desires to see in a social media content is the credibility of an advertising message's content. The third item represents that respondent acknowledge an ad that is convincing. Therefore, customers value credible and convincing content that can be utilized to help them decide whether to buy a product. 
The second highest value is informativeness, in which Gen $\mathrm{Z}$ in Malang also finds it necessary for a content to be informative. The second-high value has a mean score of 4.618. The most dominating item of informativeness is the first attribute which said, "The social media advertising message content must provide a good source of product information." It is recognized that businesses should provide informative promotional message content as a good instrument of product knowledge.

The finding in this study differs from the previous researches such as Hashim et al. (2018); Dix, Ferguson, Logan, Bright, and Gangadharbatla, (2012); and Taylor, Lewin, and Strutton (2011) who stated that the critical values in an ad are entertainment and informativeness. These studies came to the conclusion that even as social media may satisfy consumers' requirements of information; it has been shown that advertising message material on social media has greater value when it becomes entertaining. Simultaneously, the entertainment factor is critical since it results in more appealing material. These kinds of differences might be related to the fact that each target population in these studies come from a different cultural background than the Malang's Generation Z.

\section{Visual Content in Advertising}

The way a business presents itself through ad design has a big impact on how successful a marketing content is. By integrating pictures and text into an attractive package, graphic design is used to explore ideas, information, and experiences (Marley, 2018). Because it develops brand awareness, communication is most successful when the business objectives align with the visual aesthetics.

According to the results developed in the verbal content, it can be concluded that the targeted audience consider a content that is both credible and informative as the fundamental value to see in a social media content. As stated by Marley (2018), an advertisement's layout and design should reflect the brand, be cost-effective, and have consistent messaging and identity components (i.e., colors, logo, artwork). Therefore, the visual content is also expected to align and give the same value as the verbal. On account of the content should collaboratively give the same impression to build the brand image and gain brand awareness.

Nguyen (2020) mentioned that whenever the target audience views information, there is $10 \%$ likelihood that the advertising will be remembered, however, when related images of the business are included, the proportion can rise to 65 percent. Being able to see the actual product being promoted encourages consumers to read the ad, which can increase the awareness of the product being advertised (Marley, 2018). Through social media, the power of visual material can attract people's attention and boost brand awareness. There are several specific forms of content that are often employed by brand strategists in the food and beverage sector and are delivering good outcomes. Food businesses might focus on food photography and advertising to increase brand awareness.

Additionally, Pracejus, Olsen, and O'Guinn (2006) recommended that white space is an important design feature to note, especially in marketing layouts. More white space in a promotional material is excellent in clearing noise and directing the attention, leading in the message being recognized. White space, according to designers, is a required artistic objective. Many advertisements are visually crowded with text and graphic components, yet white space advertising stands out because they seem distinct and stand out from the background. 
White space symbolizes credibility, authenticity, trustworthiness, quality, attractiveness, nature, leadership, premium character, modern, and upscale in advertising and marketing. In which the value of credibility is aligned with the results given from the verbal content data collection. Therefore, minimalistic style will be used as the key style in this study. Participants in the research by Olsen, Pracejus, and O'Guinn (2012) selected the goods on which white space should be utilized the most frequently, and they replied, "every product and services." The use of white space or empty space around an image will improve an ad's efficacy in achieving the desired audience.

The different components that, when integrated, produce visual art are basically the principles that make up a great design (Marley, 2018). However, there is a lack of focus in existing research to explore certain design concepts. Marley (2018) also mentioned that there are three basic forms of principles namely unity, emphasis, and perceptual factors, some of which are made up of individual principles. The design concepts are discussed in depth in the following section as the foundation to figure out the perception of the respondents regarding each item with the value of credibility and informativeness.

The foundations of unity are proximity, alignment, similarity, and repetition. Proximity assists in the organization of content inside an advertisement, making it easier for viewers to comprehend the desired layout. White space is an important aspect of proximity. While alignment is when objects should be positioned near each other on a page without being squished together, yet with just enough white space for the reader to figure out which components fit together based on their proximity. While similarity argues that once graphical items' style features are identical and consistent, the brain will interpret them as relating collectively. Next, repetition is concerned to assist create a coherent appearance, repetition may be achieved by utilizing the same fonts, visuals, colors, and shapes across a whole design (Marley, 2018).

The second design principle is the theory of emphasis which is based on the concept of a major central focus in a design. Contrast, color, depth, and proportion are all principles that help to generate attention. Contrast is when the complicated process of interpretation, which allows us to interpret visual data, is aided because viewers can distinguish elements in a design. Color may be used to generate emphasis and unity such as when colors are closely opposite each other and clearly distinguishable, like black on white, there is high contrast.

The last design principle is the perceptual forces that people encounter while seeing a visual design. The concepts of balance, continuity, figure-ground, and psychological closure are used. Firstly, when portions of the frame layout possess fair visual weight, balance is created in a visual design (Marley, 2018). Gestalt theory's figure-ground law is important since it aids consumers in identifying items or text in a design. It may be broken down into two parts: the figure itself, which is an object, and the ground that encircles it. The contrast in figure-ground is crucial (Graham, 2008). Lastly, the capacity of our minds to fill in spaces of a design is referred to as psychological closure. The following table shows how the respondents in this study perceived the survey of experimentation on the design principle of the ads. 
Table 2. The Distribution Frequency of Respondent's Answer on Design Principles

\begin{tabular}{|c|c|c|c|c|c|c|c|c|c|c|c|c|c|}
\hline \multirow{3}{*}{ Indicator } & & \multirow{3}{*}{ Item } & \multicolumn{10}{|c|}{ Respondent's Answer } & \multirow{3}{*}{ Mean } \\
\hline & & & \multicolumn{2}{|c|}{ SD } & \multicolumn{2}{|c|}{$\mathrm{D}$} & \multicolumn{2}{|c|}{$\mathrm{N}$} & \multicolumn{2}{|c|}{$\mathrm{A}$} & \multicolumn{2}{|c|}{ SA } & \\
\hline & & & $\mathrm{F}$ & $\%$ & $\mathrm{~F}$ & $\%$ & $\mathrm{~F}$ & $\%$ & $\mathrm{~F}$ & $\%$ & $\mathrm{~F}$ & $\%$ & \\
\hline \multirow{16}{*}{ UNITY } & \multirow{8}{*}{1} & 1 & 0 & 0 & 3 & 1 & 13 & 4.3 & 72 & 24 & 212 & 70.7 & 4.64 \\
\hline & & 2 & 0 & 0 & 0 & 0 & 13 & 4.3 & 84 & 28 & 203 & 67.7 & 4.63 \\
\hline & & 3 & 0 & 0 & 0 & 0 & 13 & 4.3 & 92 & 30.7 & 195 & 65 & 4.61 \\
\hline & & 4 & 0 & 0 & 0 & 0 & 13 & 4.3 & 110 & 36.7 & 177 & 59 & 4.55 \\
\hline & & 5 & 0 & 0 & 0 & 0 & 12 & 4 & 83 & 27.7 & 205 & 68.3 & 4.64 \\
\hline & & 6 & 195 & 65 & 90 & 30 & 15 & 5 & 0 & 0 & 0 & 0 & 1.40 \\
\hline & & 7 & 192 & 64 & 93 & 31 & 15 & 5 & 0 & 0 & 0 & 0 & 1.41 \\
\hline & & 8 & 189 & 63 & 99 & 33 & 12 & 4 & 0 & 0 & 0 & 0 & 1.41 \\
\hline & \multirow{8}{*}{2} & 1 & 194 & 64.7 & 81 & 27 & 25 & 8.3 & 0 & 0 & 0 & 0 & 1.44 \\
\hline & & 2 & 182 & 60.7 & 89 & 29.7 & 29 & 9.7 & 0 & 0 & 0 & 0 & 1.49 \\
\hline & & 3 & 192 & 64 & 73 & 24.3 & 35 & 11.7 & 0 & 0 & 0 & 0 & 1.48 \\
\hline & & 4 & 163 & 54.3 & 108 & 36 & 29 & 9.7 & 0 & 0 & 0 & 0 & 1.55 \\
\hline & & 5 & 200 & 66.7 & 84 & 28 & 16 & 5.3 & 0 & 0 & 0 & 0 & 1.39 \\
\hline & & 6 & 0 & 0 & 0 & 0 & 29 & 9.7 & 90 & 30 & 181 & 60.3 & 4.51 \\
\hline & & 7 & 0 & 0 & 0 & 0 & 29 & 9.7 & 86 & 28.7 & 185 & 61.7 & 4.52 \\
\hline & & 8 & 0 & 0 & 0 & 0 & 29 & 9.7 & 90 & 30 & 181 & 60.3 & 4.51 \\
\hline \multirow{16}{*}{ EMPHASIS } & \multirow{8}{*}{1} & 1 & 0 & 0 & 0 & 0 & 31 & 10.3 & 88 & 29.3 & 181 & 60.3 & 4.50 \\
\hline & & 2 & 0 & 0 & 0 & 0 & 27 & 9 & 102 & 34 & 171 & 57 & 4.48 \\
\hline & & 3 & 0 & 0 & 0 & 0 & 24 & 8 & 75 & 25 & 201 & 67 & 4.59 \\
\hline & & 4 & 0 & 0 & 0 & 0 & 23 & 7.7 & 79 & 26.3 & 198 & 66 & 4.58 \\
\hline & & 5 & 0 & 0 & 0 & 0 & 21 & 7 & 79 & 26.3 & 200 & 66.7 & 4.60 \\
\hline & & 6 & 189 & 63 & 85 & 28.3 & 26 & 8.7 & 0 & 0 & 0 & 0 & 1.46 \\
\hline & & 7 & 186 & 62 & 81 & 27 & 33 & 11 & 0 & 0 & 0 & 0 & 1.49 \\
\hline & & 8 & 198 & 66 & 72 & 24 & 30 & 10 & 0 & 0 & 0 & 0 & 1.44 \\
\hline & \multirow{8}{*}{2} & 1 & 168 & 56 & 98 & 32.7 & 34 & 11.3 & 0 & 0 & 0 & 0 & 1.55 \\
\hline & & 2 & 173 & 57.7 & 100 & 33.3 & 27 & 9 & 0 & 0 & 0 & 0 & 1.51 \\
\hline & & 3 & 173 & 57.7 & 101 & 33.7 & 26 & 8.7 & 0 & 0 & 0 & 0 & 1.51 \\
\hline & & 4 & 173 & 57.7 & 96 & 32 & 31 & 10.3 & 0 & 0 & 0 & 0 & 1.53 \\
\hline & & 5 & 161 & 53.7 & 111 & 37 & 28 & 9.3 & 0 & 0 & 0 & 0 & 1.56 \\
\hline & & 6 & 0 & 0 & 0 & 0 & 24 & 8 & 84 & 28 & 192 & 64 & 4.56 \\
\hline & & 7 & 0 & 0 & 0 & 0 & 21 & 7 & 96 & 32 & 183 & 61 & 4.54 \\
\hline & & 8 & 0 & 0 & 0 & 0 & 27 & 9 & 93 & 31 & 180 & 60 & 4.51 \\
\hline \multirow{16}{*}{$\begin{array}{l}\text { PERCEPTUAL } \\
\text { FORCES }\end{array}$} & \multirow{8}{*}{1} & 1 & 0 & 0 & 0 & 0 & 17 & 5.7 & 88 & 29.3 & 195 & 65 & 4.59 \\
\hline & & 2 & 0 & 0 & 0 & 0 & 17 & 5.7 & 92 & 30.7 & 191 & 63.7 & 4.58 \\
\hline & & 3 & 0 & 0 & 0 & 0 & 17 & 5.7 & 98 & 32.7 & 185 & 61.7 & 4.56 \\
\hline & & 4 & 0 & 0 & 0 & 0 & 32 & 10.7 & 89 & 29.7 & 179 & 59.7 & 4.49 \\
\hline & & 5 & 0 & 0 & 0 & 0 & 23 & 7.7 & 94 & 31.3 & 183 & 61 & 4.53 \\
\hline & & 6 & 172 & 57.3 & 89 & 29.7 & 39 & 13 & 0 & 0 & 0 & 0 & 1.56 \\
\hline & & 7 & 170 & 56.7 & 106 & 35.3 & 24 & 8 & 0 & 0 & 0 & 0 & 1.51 \\
\hline & & 8 & 193 & 64.3 & 86 & 18.7 & 21 & 7 & 0 & 0 & 0 & 0 & 1.43 \\
\hline & & 1 & 187 & 62.3 & 81 & 27 & 32 & 10.7 & 0 & 0 & 0 & 0 & 1.48 \\
\hline & & 2 & 165 & 55 & 99 & 33 & 36 & 12 & 0 & 0 & 0 & 0 & 1.57 \\
\hline & & 3 & 186 & 62 & 78 & 26 & 36 & 12 & 0 & 0 & 0 & 0 & 1.50 \\
\hline & & 4 & 164 & 54.7 & 100 & 33.3 & 36 & 12 & 0 & 0 & 0 & 0 & 1.57 \\
\hline & 2 & 5 & 181 & 60.3 & 85 & 28.3 & 34 & 11.3 & 0 & 0 & 0 & 0 & 1.51 \\
\hline & & 6 & 0 & 0 & 0 & 0 & 27 & 9 & 86 & 28.7 & 187 & 62.3 & 4.53 \\
\hline & & 7 & 0 & 0 & 0 & 0 & 27 & 9 & 84 & 28 & 189 & 63 & 4.54 \\
\hline & & 8 & 0 & 0 & 0 & 0 & 27 & 9 & 84 & 28 & 189 & 63 & 4.54 \\
\hline
\end{tabular}

According to Table 2, it can be concluded that the experiment for the strong value of each design principle shows a great number of the overall score. Which means that a great number of respondents agreed that they prefer ad design to implement the design principles in the visuals of an ad. Moreover, the strong design principal experiments are perceived to not need a lot of improvement to be more appealing and that respondents found this ad is easy to look at and read the information. Meanwhile, the weak design principle which is labeled as the number 2 of each indicator shows that respondents do not have a positive perception and they suggested for the ads to have a lot of improvement to be perceived as appealing. Additionally, this weak value also indicated that the respondents have difficulty to look and read the ads. Therefore, ad design with strong design principles is in the respondent's favor and marketers or advertisers of Granoolars should consider it as a crucial matter. 


\subsubsection{Enhance Design Problem}

After finishing the divergent research, there are several closures that enhance the design problem. While learning the consumer preference on the marketing content they would like to see on a social media ad, the framework of a clearer guide. Firstly, the marketing content should offer the value of credibility and informativeness. The selection of typography and color palette should align the overall brand image. Then, the graphic presentation should be simple and represent strong design principles. Imagery mostly should be photographic to build credibility value.

\subsubsection{Agreed Design Objective}

Following the proposed design, there are a set of feasible and realistic objectives as the criteria. The design must be high in readability and able to deliver the messages of Granoolars. Then, it must also appeal to the target consumer. Lastly, it should represent the value of the business and the target audience equally.

\subsubsection{Agree Channel of Distribution}

Thereafter figuring out the characteristics of promotional content that the targeted audience preferred, the distribution channel for the message delivery is critical. Nguyen (2020) concluded from a public article called Inkbot Design, a Creative Branding Agency (2018), that using social media to produce informative, engaging, and relatable material is a new and extremely successful approach for modern businesses to build brand awareness. This will foster a bond and relationship between consumers and the business, converting them into prospective consumers. Moreover, Nguyen (2020) also discovered a report from Snalderman's 2019 Restaurant Report, which surveyed over 800 food owners and managers, shows how social media affects the food and beverage business. Businesses with yearly profit increases indicated that 82 percent of them communicate with consumers via social media.

Additionally, social media is chosen since the targeted consumers of Gen $\mathrm{Z}$ are a key contributor in the growth of users. As per the Global Web Index, Gen Z in Indonesia now overtaken Millennials in terms of daily social media usage, consuming about 3 hours per day on the platform. Therefore, social media is a promising channel of distribution to meet the prospective consumer.

People nowadays consume content across many platforms, forcing advertisers and marketers to increase the effectiveness of advertising messages by boosting consumer media interaction. Cross-channel integration is used since repetition would increase the exposure of brand information. A business must also carefully select the social media channels that will most successfully reach their target consumers. Channels are often chosen based on the features and functionalities, as well as the quantity of potential users.

Among all the social media sites accessible in Indonesia, there are a few that are the most popular. They are YouTube, Facebook, Instagram, and Twitter, according to the statistics (StatCounter Global Stats, 2021). Consumers are more likely to accept media content across several social media sites. As a result, if the proper advertising message material is distributed via the appropriate social media channels, it may have a big impact.

The survey in this study also included the item of which social media that the respondents are actively using. The following pie chart represents the answers: 


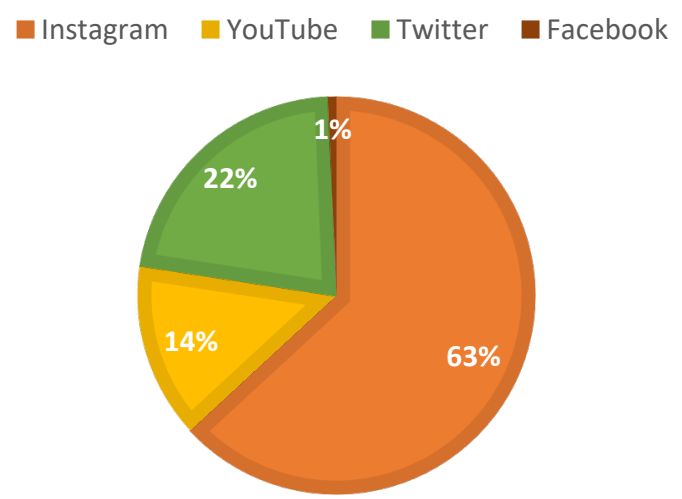

\section{Figure 5. The Number of Respondents on Most Used Social Media Platforms}

According to Figure 2, it can be concluded that the respondents of this study mostly used Instagram and Twitter. About 190 people are mostly using Instagram while a number of 66 out of 300 respondents choose to be more active on Twitter. The sum of people in the study that use YouTube as the primary social media are 43 people. Lastly, Facebook only has 2 active users from the overall respondents. In conclusion, the distribution channels that will be used as a social media mix strategy in this study are Instagram and Twitter.

\subsection{Transformation}

The overall concept is using the white space layout where pictures are highlighted almost in every promotional content. Since content that shows the real picture of the brand us perceived as credible and informative by the respondents. The simple and elegant design is also implemented for representing the brand of middle- and upper-income target audience.

\subsubsection{Elements of Design}

\section{Brand Identity Granoolars}

The identity of the brand will be highlighted in the design. It includes the logo and the tone and manner as the starter point of the whole design. The theme for design is aligning with the tone and manner which implements the earth tone. The word choices will align with the given key word as well. The logo itself already uses the Arial Rounded MT Bold. This font represents how dynamic the brand is and that it produces snacks for highly active people as a grab-to-go option.

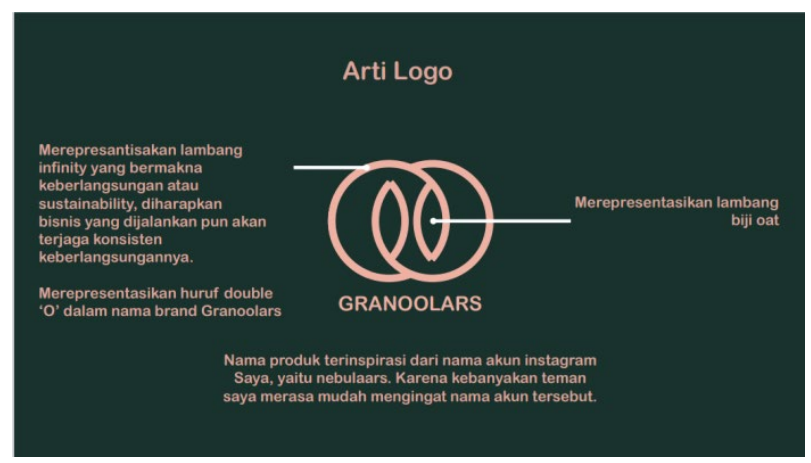

Figure 6. Logo Granoolars Brand 


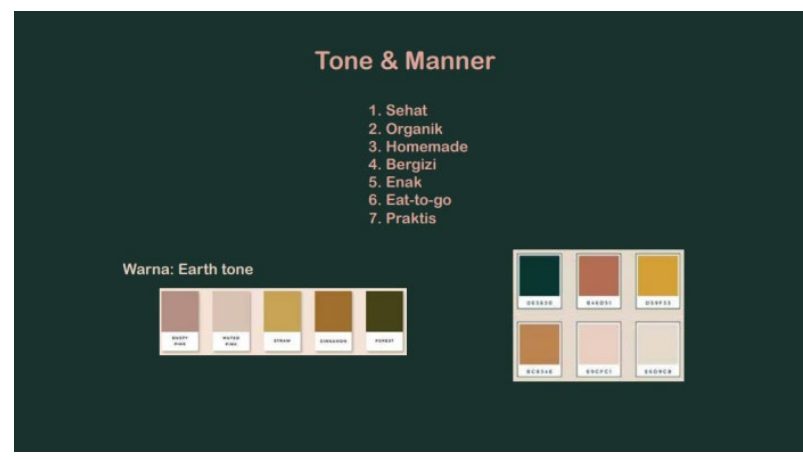

Figure 7. Tone \& Manner Granoolars Brand

\section{Font and Color Palette}

The headline uses Barlow font with the Black Italic or Bold Italic font style. This font gives a bold and strong look that can emphasize the headline of the content. The font size is 70pt All Caps and adapted to the other element in one page. If there should be any sub headlines, the font is also Barlow but with medium font style. This still gives emphasis to the headline and body text. While the body text is using Arial Rounded MT Bold. For the color palette, we follow the tone of the brand which is earth tone. However, a selection of schemes is selected as mentioned in Figure 8.

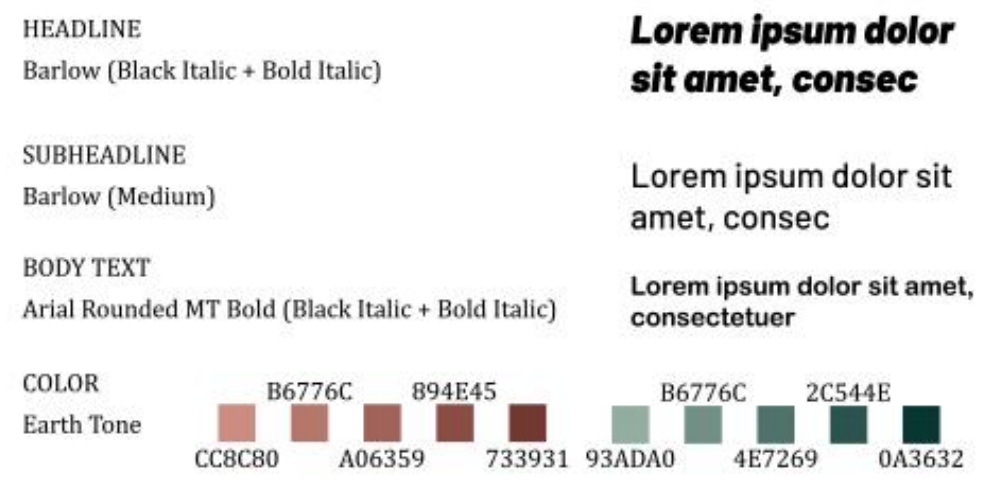

Figure 8. Font and Color Pallet of the Promotional Content Design

\subsubsection{Instagram}

Since Instagram is the main distribution channel, the design was made according to the orientation of the Instagram post of a $1 \mathrm{x} 1$ square. The content plan in the early stage divides the contents into several categories such as Product, Process, Discount, Trivia, National/International day celebration, and Interactive Content. To be systematic, a content calendar is also implemented for the promotional plan. The following is the month of launching's content calendar plan. 


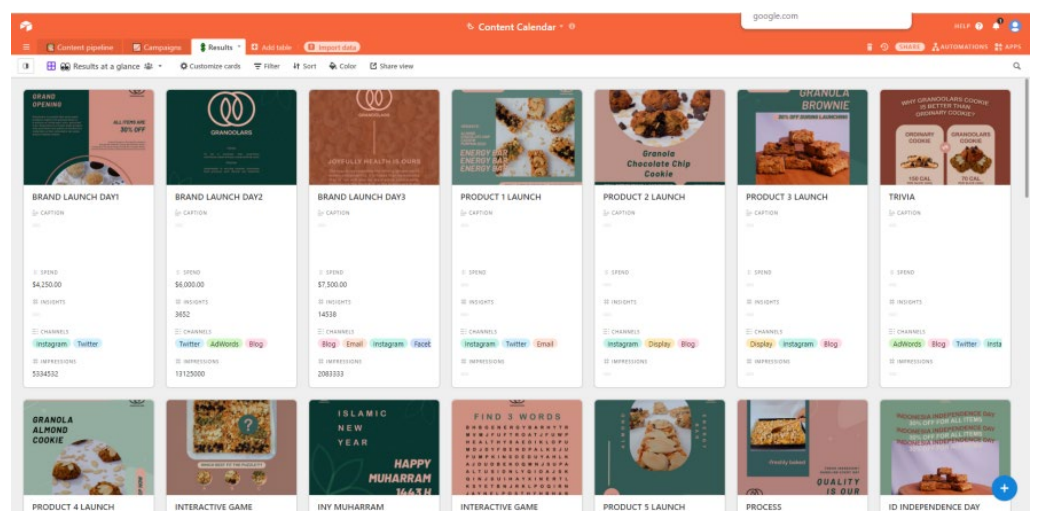

Figure 9. Content Calendar

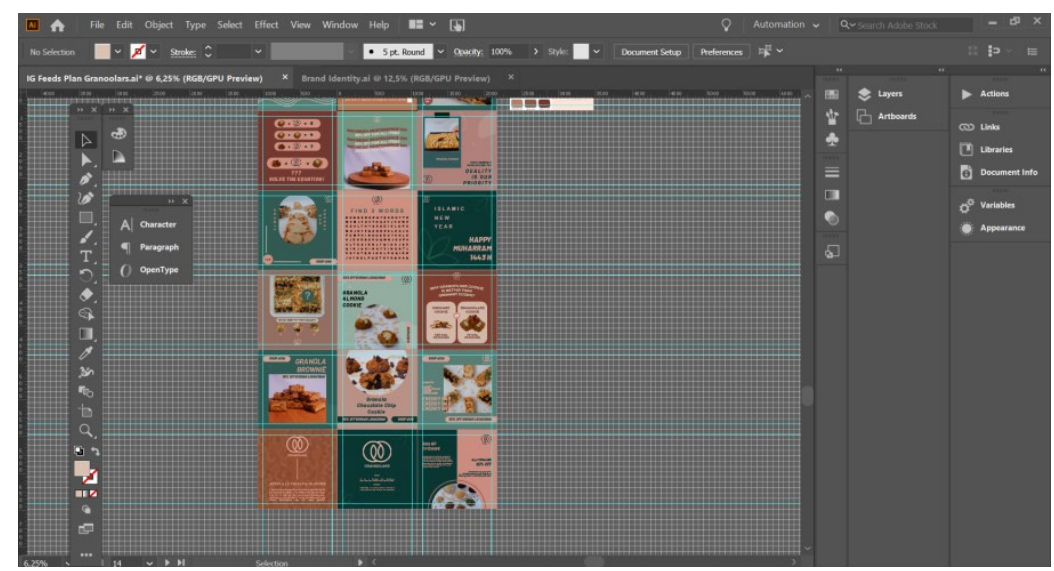

Figure 10. Final Design of The First 15 Content

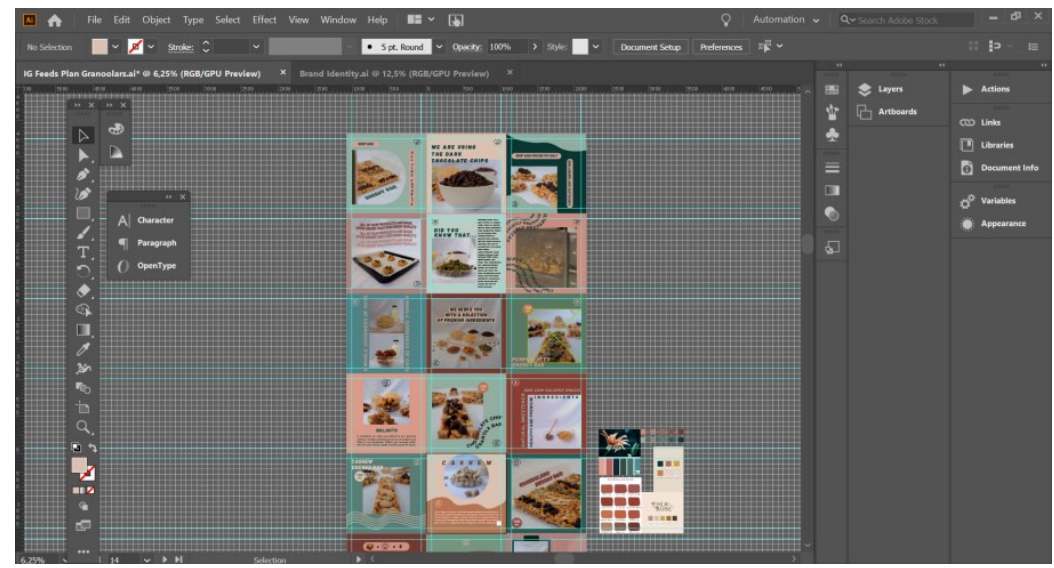

Figure 11. Final Design of The Second 15 Content

\subsubsection{Twitter}

Another distribution channel is also twitter. Since twitter is a micro-blogging social media, the short captioning is also utilized to engage and gain the audience's awareness. Moreover, the picture is taken from the Instagram post so that the channels will be integrated and connected between one another. The following is an overview of how the design of the twitter platform will be. 

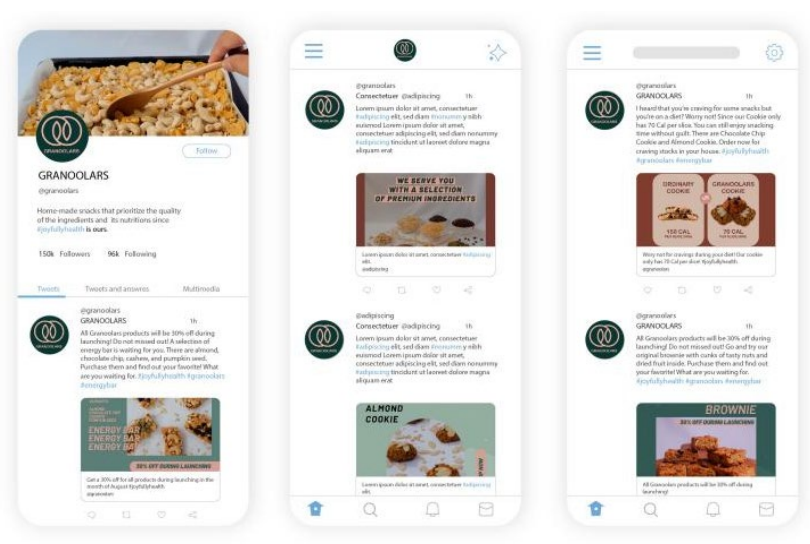

Figure 12. Twitter Distribution Channel

\section{Conclusion}

The suggestion from this research is for the marketer or advertiser of Granoolars to provide the ad value of credibility and informativeness in the promotional content. Moreover, the visuals of ads that have a strong value of design principle is more favorable than the weak one. The respondents in this study are mostly active on Instagram and Twitter. Therefore, it can be a consideration to utilize both channels to deliver the message content. Picture is highlighted in the design since it is perceived as more credible especially for the food business. The study was conducted in the best effort to generate the desirable outcome, hence there still need improvements for further Granoolars business growth. A video-based ad can also be beneficial to further advance the promotional approach of the brand. Moreover, a variation of marketing strategy will also be needed after the brand gains consumer awareness in the early stage of launching. The creatives of Granoolars need to consider marketing approaches to be the top-of-mind brand in a healthy food industry through the visuals of the promotional content.

\section{References}

Agustina, Y., Winarno, A., Pratikto, H., Narmaditya, B.S., \& Filianti, F. (2020). A creative economy development strategy: The case of Trenggalek creative network for Trenggalek Regency, Indonesia. Journal of Asian Finance, Economics and Business, 7(12), 1111-1122. doi: https://doi.org/10.13106/JAFEB.2020.VOL7.N012.1111

BEKRAF. (2019). OPUS: Creative economy outlook 2019 (English version). Retrieved from https://www.kemenparekraf.go.id/asset_admin/assets/uploads/media/pdf/media_1589839632_OP US_-_Creative_Economy_Outlook_2019_(English_Version).pdf

Brodie, R.J., Hollebeek, L.D., Ilić, A., \& Jurić, B. (2011). Customer engagement: Conceptual domain, fundamental propositions, and implications for research. Journal of Service Research, 14(3), 252-271. doi: https://doi.org/10.1177/1094670511411703

Dehghani, M., \& Tumer, M. (2015). A research on effectiveness of Facebook advertising on enhancing purchase intention of consumers. Computers in Human Behavior, 49, 597-600. doi: https://doi.org/10.1016/j.chb.2015.03.051

Dix, S., Ferguson, G., Logan, K., Bright, L.F., \& Gangadharbatla, H. (2012). Facebook versus television: Advertising value perceptions among females. Journal of Research in Interactive Marketing, 6(3), 164179. doi: https://doi.org/10.1108/17505931211274651

Ducoffe, R.H. (1996). Advertising value and advertising the Web. Journal of Advertising Research, 36(5), 21-35. 
Graham, L. (2008). Gestalt theory in interactive media design. Journal of Humanities \& Social Sciences, 2(1), 112. Retrieved from http://www.guillaumegronier.com/2020-miashs/resources/Graham,-2008.pdf

Hashim, N.H., Normalini, \& Sajali, N. (2018). The influence factors towards mobile advertising message content on consumer purchase intention. Global Business Review, 19(5), 1187-1206. doi: https://doi.org/10.1177/0972150918788746

Inkbot Design. (2016). New Instagram logo design feedback \& expert opinion. Retrieved from https://inkbotdesign.com/new-instagram-logo-design/

Lehrer, J. (2006). Design Studies: Theory and Research in Graphic Design, (A. Bennett, Ed.). New York: Princeton Architectural Press, 60(5), 172.

MacKenzie, S.B., \& Lutz, R.J. (1989). An empirical examination of the structural antecedents of attitude toward the ad in an advertising pretesting context. Journal of Marketing, 53(2), 48-65. doi: https://doi.org/10.2307/1251413

Marley, M.L. (2018). Effects of visual design in beef seedstock ads on trust, credibility, and intent to seek more information. (Master's thesis, Colorado State University, Colorado). Retrieved from https://mountainscholar.org/bitstream/handle/10217/191387/Marley_colostate_0053N_14977.pdf ?sequence $=1 \&$ isAllowed $=y$

Nguyen, T. (2020). Designing a social media marketing plan for brand awareness enhancement: Case study of KOKORO restaurant. (Undergraduate thesis, Laurea University of Applied Sciences, Finland). Retrieved from https://www.theseus.fi/handle/10024/344133

Noble, I., \& Bestley, R. (2005). Visual research: An introduction to research methodologies in graphic design. Lausanne: AVA Publishing SA.

Olsen, G.D., Pracejus, J.W., \& O'Guinn, T.C. (2012). Print advertising: White space. Journal of Business Research, 65(6), 855-860. doi: https://doi.org/10.1016/j.jbusres.2011.01.007

Pracejus, J.W., Olsen, G.D., \& O'Guinn, T.C. (2006). How nothing became something: White space, rhetoric, history, and meaning. Journal of Consumer Research, 33(1), 82-90. doi: https://doi.org/10.1086/504138

Pulizzi, J. (2012). The rise of storytelling as the new marketing. Publishing Research Quarterly, 28(2), 116-123. doi: https://doi.org/10.1007/s12109-012-9264-5

Rodgers, S., \& Thorson, E. (2018). Special issue introduction: Digital engagement with advertising. Journal of Advertising, 47(1), 1-3. https://doi.org/10.1080/00913367.2017.1414003

Sekaran, U. (2003). Research and markets: Research methods for business - A skill building approach. New York: John Wiley \& Sons.

Siau, K., \& Shen, Z. (2003). Mobile communications and mobile services. International Journal of Mobile Communications, 1(1-2), 3-14. doi: https://doi.org/10.1504/ijmc.2003.002457

Snalderman, D. (2019). The 12 best restaurant website examples. Toast. Retrieved from https://pos.toasttab.com/blog/examples-restaurant-websites?fbclid=IwAR00xx8LBFJiLaZsoevP1Yg wnbqTVME4EWErWm08jsvGlY2IL70j-9FuCo

StatCounter Global Stats. (2021). Social Media Stats Indonesia. Retrieved from https://gs.statcounter.com/social-media-stats/all/indonesia

Taylor, D.G., Lewin, J.E., \& Strutton, D. (2011). Friends, fans, and followers: Do ads work on social networks? How gender and age shape receptivity. Journal of Advertising Research, 51(1), 258-275. doi: https://doi.org/10.2501/JAR-51-1-258-275

Yu, J. (2006). Visual communication design strategies: Multidisciplinary human-centered approach in branding and marketing. (Master's thesis, Auckland University of Technology, New Zealand). Retrieved from https://core.ac.uk/download/pdf/56360912.pdf 